\title{
Pragmatical rules for success in persuasion
}

\author{
Daniela Gîfu ${ }^{1, *}$, Mirela Teodorescu ${ }^{2}$, Dan lonescu ${ }^{3}$ \\ 1"Alexandru loan Cuza" University of laşi, Bd. Carol I no. 11, Iaşi, 700506, Romania \\ ${ }^{2}$ University University of Craiova, 13 A. I. Cuza Street, Craiova, 200585, Romania \\ 3“Nicolae Titulescu” High School, Doljului Street, Craiova, Romania \\ *E-mail address: danigifu@yahoo.com
}

\begin{abstract}
The study reveals how to be successful, how to make friends, how to become influential, which are desires, goals for most of us. There is no manual, no theory, only rules, principles which work like a spell. From Aristotle to the present day we have been looking for the path to success. Persuasion through its mechanisms, strategies and methods, constitutes a way to success. The presentation of these rules, as structure, is based on the concept of "The Magical Number Seven, Plus or Minus Two" by psychologist George Miller. These rules have been tested in practice, and became the golden rules for those who strived for success. G. B. Shaw remarked: "No one will ever learn what is taught" - learning is an active process, we learn as we act, and only applied science remains in mind. Napoleon Hill said, "Persuasion is the magic ingredient that will help you to forge ahead in your profession or business and to achieve happy and lasting personal relationships." As we all know, persuasion is the skill of the ultra-prosperous. It is how people gain power and influence. It is how people create staggering wealth - how businesses thrive, how books are published, how properties are purchased, and how Web sites sell millions of dollars worth of product. Persuasion is the life-blood of powerful and effective day-today living. The art of persuasion is what makes the world turn (Hill, 1928).
\end{abstract}

Keywords: persuasion; principles of persuasion; influence; conviction

\section{INTRODUCTION}

In his article, "The magical number seven, plus or minus two: Some limits on our capacity for processing information", George Miller revealed a coincidence between the limits of onedimensional absolute judgment and the limits of short-term memory. So, people's maximum performance on one-dimensional absolute judgment can be characterized as an information channel capacity with approximately 2 to 3 bits of information, which corresponds to the ability to distinguish between four and eight alternatives. So, number 6 is optimal for rules selecting. In persuasion, this phenomenon can be interpreted like this: if you want to learn to argue well, the number of simple operations that you should exercise once with a stable performance is 6 . Consequently, the concept of argumentation is treated in study starting from of the idea 6 questions, to which a message has to answer. Also, this is available for the ability of analysis after interaction, 6 evaluation criteria or for sensitivity development, 6 indices (Miller, 1968).

The Aristotle's Rhetoric is a doctrine that defines three technical means of persuasion, that implies two characteristics: (1) Technical persuasion must retrieve on a method - we must 
know the reason why some things are persuasive and some are not; (2) Technical means of persuasion must be provided by the speaker himself, whereas preexisting facts, such as oaths, witnesses, testimonies, etc. are non-technical, since they cannot be prepared by the speaker (Aristotle, 2004).

A discourse consists of three elements: the speaker, the subject that is dealt with within the speech, and the listener to whom the discourse is addressed. Technical means of persuasion are either (a) in the character of the speaker (ethos), (b) in the emotional state of the hearer (pathos), or (c) in the argument (logos) itself (Aristotle, 2004).

(a) Ethos (credibility) - the persuasion is performed by a character whenever the discourse is held in such a way as to render the speaker worthy of credence. In the case of credibility, the audience will form the second-order judgment according to which propositions put forward by the credible speaker are true or acceptable. The tools that a credible person wields are practical intelligence, a virtuous character and good will.

(b) Pathos (emotional) - the success of the persuasive efforts depends on the emotional dispositions of the audience; as individuals we do not judge in the same way when we grieve and rejoice or when we are friendly and hostile. Thus, the orator has to arouse emotions precisely because emotions have the power to modify our judgments: to a judge who is in a friendly mood, the person whom he is going to judge seems not to do wrong at all or seems to do so only to a certain extent; but to the judge who is in an angry mood, the same person will seem to do just the opposite. Aristotle's technique is essentially based on the knowledge of the definition of every significant emotion. For example, anger can be defined as "desire, accompanied with pain, for conspicuous revenge for a conspicuous slight that was directed against oneself or those near to one, when such a slight is undeserved" (Aristotle, 2004). The orator who wants to arouse emotions must not even speak outside the subject; it is sufficient to detect aspects of a given subject that are causally connected with the intended emotion.

(c) Logos (Logical) - persuading by the argument itself when we demonstrate or seem to demonstrate that something is the case. For Aristotle, there are two species of arguments: inductions and deductions (Aristotle, 1961, Posterior Analytics.). Induction is defined as the proceeding from particulars up to a universal (Aristotle, 1961, Topics.) and deduction is an argument in which, certain things having, been supposed, something different from the suppositions results of necessity through them (Aristotle, 1961, Topics) or because of their being true (Aristotle, 1961, Prior Analytics). The inductive argument in rhetoric is the example (paradeigma); unlike other inductive arguments, it does not proceed from many particular cases to one universal case, but from one particular to a similar particular if both particulars fall under the same genus (Aristotle, 2004). The deductive argument in rhetoric is the enthymeme: but when, certain things being the case, something different results beside them because of their being true, either universally or for the most part, it is called deduction here (in dialectic) and enthymeme there (in rhetoric).

It is remarkable that Aristotle uses the qualification "either universally or for the most part": obviously, he wants to say that in some cases the conclusion follows universally, i.e., by necessity, while in other cases it follows only for the most part. At first glance, this seems to be inconsistent, since a non-necessary inference is no longer a deduction. 


\section{THE PRACTICAL PRINCIPLES OF PERSUASION}

\section{1. Focus on goals}

The only way to influence others is to talk about what they want and show them how to fulfill their desires.

Any action that you have done from the moment that you were born was motivated by the fact that you wanted something (Carnegie, 1964). "The engine of our action is a fundamental desire that we feel and the best advice for those who claim to persuade, in business, home, school or in politics, is first of all, aroused in others a live desire. Whoever is in this state, has the world at his feet. Who does not, is condemned to solitude", asserts Harry A. Overstreet in his book, "Influenting Human Behavior".

"If there is any secret of success, it lies in the ability to understand the other's point of view and to see things from the perspective of both his and yours", said Henry Ford, as one of the best advice in the delicate art of relationships.

The time allotted for preparing a process of persuasion is an absolutely essential resource for success. We tend to have many meetings and superficial interactions instead we prefer fewer but more significant and well-prepared ones. Long-term partnerships take time to form and the key moments of the first meetings cannot be "magical" unless they are prepared. The tool with which these meetings are prepared constitutes the goal of negotiation (Szekely, 2013). So, what we don't see clear, we rarely achieve!

\section{2. Capture the attention of interlocutor}

Attention is the ability to see from multiple perspectives, the reality that could help you accomplish your goals. To obtain performance including persuasion, you need to practice focus of attention. Besides focusing, the ability to "step back" to gain perspective is also important. Thus, the return of attention to the maximum intensity in the process, you get access to new information, useful for achieving goals (Szekely, 2013; Vladutescu, 2014). In persuasion, this form of attention is essential. It is necessary to see in the same time what your interlocutor is doing, to hear what he says, to notice some reactions to stimuli or questions in order to monitor his emotions, to think quickly and logically based on information you receive and to make proposals for solving the tense situation to receive a positive feedback (Carnegie, 1964).

Socrates, "'Athens annoyance "was one of the greatest philosophers of the world. He did something that only few people throughout history have been able to do: completely changed the course of human thought; and now 2400 years after his death, is celebrated as one of the most subtle wise persuasion that influenced this world ever needed. His method? Does he tell people that they are wrong? No, never. He was too clever for such a move. His whole technique, called "the method of Socrates" based on asking questions that could get only "yes" as an answer. He won approval after approval, to have a considerable reserve of "yes". He asked further questions until, towards the end, almost unconsciously, his interlocutors was situated in the awkward position of accepting a conclusion that, with just a few minutes ago, denied it firmly (Carnegie, 1964). Also we have to take into consideration the Chinese proverb that gather the whole wisdom of the Old Orient: "That one who walks slowly will get very far".

\section{3. Approaching a stylish and structured manner}

This is the principle of similarity, according to which people are attracted to people who resemble them and reject people who are different. This mechanism has strong roots in the evolution of mankind. The human mind requires reaction speed, will do a quick analysis like: those who are the same with me, is a friend; you are different from me, you are my potential 
danger. Besides style, much substance, documentation and solid argumentation are also needed. In this case, the caller can be passive or aggressive assertive (Vladutescu, 2006).

Kenneth M. Goode said in his book How to turn people into gold: "Stop a moment and compare the acerbic interest that you manifest in certain problems with weaker concern for anything else. Figure out like everyone else around you, feel the same! ... the fundamental secret of approaching the interpersonal relationships, namely that the success in communicating with others depends on a correct approach and open to their point of view ". There is a reason for the thought and action of the other. Try to look for it and to discover it and get the key motivation of his actions and even his personality Carnegie, 1064, Szekely,2013).

\section{4. Correct identification of a situation}

Always we opt for what appears to be the best possible choice at that point. People can act in a cynical or malicious manner, but they will always believe that they have something to gain. If you proceed as if there is a default need and try to find out what they actually watch your interlocutors, you'll have more chances to influence them. Efficiency in this case is the method of "5 Whys", can thus reach the root cause, the default deepest need (Gifu \& Teodorescu, 2014).

Once one empathizes with motivation of a person's behavior, with the default need, one really gets to change one's perspective on that person. At that point, you will treat that person differently and may get a positive response.

The only factor that motivates people is the work itself. If the work is interesting and stimulating, the employee is enthusiastic to do it and will perform well. That which every successful person loves is the game. The chance to self expression. The chance to prove their value to surpass himself, to win. That causes people to participate in activities, events, desire to be the best, the desire to feel important.

\section{5. Evaluation means evolution}

Great performers have a very special feature: periodically evaluates the evolution towards their long-term goals, use feedback, not fantasies. Performance evaluation on the way to the goal achieving, is the essence of any successful activity. Any project requires three essential elements to ensure the success: a clearly defined objective, an efficient process, a mechanism for measuring / evaluation of the process. In persuasion, the objective is that you prepare before the meeting, the process is given by using the essential skills of persuasion in real time evaluation, the mechanism of the evaluation is the process of the analysis and evaluation that takes place during and after the action process. It is a very important step, is one of the great secrets of top influential persons. A famous model of evaluation and analysis of negotiation discussions is offered by "steel king" Andrew Carnegie. His method was documented by experts and is now used by famous negotiators. It has a very strong psychological tinge. Here's how he performed it: he himself often negotiate at its headquarters and his negotiating partners came in teams of 5-6 experts on the position of chief negotiator, technical expert, financier ... After about a half hour of early negotiations, Carnegie requested a break of half an hour still, claiming the need for additional documentation. Meanwhile, withdrew into a room, a miniature replica of the negotiating room and remembered the dialogue from the perspective of others. As strange as it may seem this way, after this recall, Carnegie predicts the movements of the negotiating team and prepared several counter proposals that could continue negotiating. 


\section{6. The context triggers the approach}

The context is the reference frame that a person places it around a given situation. It creates the meaning of the situations, respectively the person in question. When influencing someone it is required that the interlocutor remains in the original context, which is achieved by flexibility and creativity, adapting to the "movements of the other". You need skills such as: anticipation, acuity, harmonization, argumentation, analysis. Combined, these skills can position yourself among those with the power of persuasion.

These principles have a sequential action, each has its place and role in the process. Also in persuasion the Pareto principle is applied - 80/20 - and suggest that $80 \%$ of the obtained results, corresponding to $20 \%$ of the efforts made. Basically, if you apply $80 / 20$ rule again for the first $20 \%$ of efforts, you get a very small percentage of activities that need to focus in order to maximize the effects of your work (Szekely, 2013; Gifu \& Teodorescu, 2014, Vladutescu, 2014). Persuasion techniques, to be effective, need an understanding of what persuasion is and the elements of persuasion needed for a smooth process. Aren't we trying to get someone to buy something when we persuade them? Persuasion techniques are designed to "sell", product, idea, concept, suggests... And persuading is a key of communication skill that helps you achieve influence with others and vital learning. You can win over others by convincing them that there are benefits to achieve from whatever it is you want to influence them to do. The key word here is benefits. The tools of persuasion are centered on benefits: when you buy something (whether it be a car or insurance or a holiday or an idea or a donation to a charity), you don't really buy what it is, you buy what you believe it will do for you. You buy the benefits. You buy your perception of, "what's in it for you" (Dima \& Vladutescu, 2012).

\section{ABILITIES OF PERSUASION MASTERS}

There are 6 important abilities that every person who wants to get success in his activity must have: anticipation, acuity, harmonization, argumentation, analysis, amplification. They can be divided into three cathegories (Borowski, 2014):

- Persuasion abilities for long term- referring to your competences to look the influencing process in evolution, not only in current moment, represented by: anticipation (how to prepare a meeting) and analysis (evaluation of the process);

- Persuasion abilities in real time - referring to necessary competences in front of your interlocutors such as: acuity, harmonization, argumentation;

- Persuasion abilities interrelated -referring to above mentioned abilities that together used have the role to amplify the effect, to increase convincing force using all persuasion competences in the same time.

\section{ROBERT CIALDINI'S 6 KEY PRINCIPLES OF INFLUENCE}

Robert Cialdini identified and developed the six principles through his experimental studies, and by immersing himself in the world of what he called "compliance professionals" - salespeople, fund raisers, recruiters, advertisers, marketers, and so on. These are people skilled in the art of convincing and influencing others (Cialdini, 2001). The six principles are as follows: 


\section{1. Reciprocity}

Cialdini's rules says: "that we should try to repay, in kind, what another person has provided us. If a woman does us a favor, we should do her one in return; if a man sends us a birthday present, we should remember his birthday with a gift of our own; if a couple invites us to a party, we should be sure to invite them to one of ours. By virtue of the reciprocity rule, then, we are obligated to the future repayment of favors, gifts, invitations, and the like. So typical is it for indebtedness to accompany the receipt of such things that a term like "much obliged" has become a synonym for "thank you", not only in the English language but in others as well" (R. Cialdini, 2001). As humans, we generally aim to return favors, pay back debts, and treat others as they treat us. According to the idea of reciprocity, this can lead us to feel obliged to offer concessions or discounts to others if they have offered them to us. This is because we're uncomfortable with feeling indebted to them. To use reciprocity to influence others, you'll need to identify your objectives, and think about what you want from the other person. You then need to identify what you can give to them in return.

\section{2. Commitment (and Consistency)}

People want to appear consistent in beliefs, attitudes and actions. Coherence and consistency are highly valued by society and we are educated in this spirit. Consistency is beneficial behavior, is valuable in making decisions and is consistent with previous decisions.

Cialdini says: "To understand why consistency is so powerful a motive, it is important to recognize that in most circumstances consistency is valued and adaptive. Inconsistency is commonly thought to be an undesirable personality trait. The person whose beliefs, words, and deeds don't match may be seen as indecisive, confused, two-faced, or even mentally ill. On the other side, a high degree of consistency is normally associated with personal and intellectual strength. It is at the heart of logic, rationality, stability, and honesty" (R. Cialdini, InfluenceThe Psychology of Persuasion, p. 45). We have a deep desire to be consistent. For this reason, once we've committed to something, we're then more inclined to go through with it. For instance, you should probably be more likely to support a colleague's project proposal if you had shown interest when he first talked to you about his ideas. Here, try to get people's commitment early on, either verbally or in writing. Commitment is the key.

\section{3. Social Proof}

People tend to determine what is correct by finding out what other people think is right. We adopt a behavior in agreement with the general belief, very quickly. Adoption unanimity belief is even stronger as uncertainty is higher, more ambiguous status and authority that shows what the group belief, stronger.

Cialdini asserts: "The tendency to see an action as more appropriate when others are doing it normally works quite well. As a rule, we will make fewer mistakes by acting in accord with social evidence than contrary to it. Usually, when a lot of people are doing something, it is the right thing to do. This feature of the principle of social proof is simultaneously its major strength and its major weakness. Like the other weapons of influence, it provides a convenient shortcut for determining how to behave but, at the same time, makes one who uses the shortcut vulnerable to the attacks of profiteers who lie in wait along its path" (R. Cialdini, InfluenceThe Psychology of Persuasion, p. 88).

This principle relies on people's sense of "safety in numbers". Or, if you are selling a service, highlight the number of people using it, use plenty of relevant testimonials, encourage 
people to talk about it using social media, and publish case studies with current customers to demonstrate its success.

\section{4. Liking}

Somebody will say "yes" much easier to a request coming from a person who knows and likes. We, the people, we want to be liked by others and we also want to show us this.

There are few things that generate the sympathy:

- Physical attractiveness - that halo effect that extends to favorable impressions physical appearance on other traits, such as talent, kindness, intelligence;

- Similarity - we like people who are like us. We tend to say yes to these people. In sales this means studying the behavior of partners and their hobbies and exploiting them;

- Compliments - we like appraisals and using them can generate sympathy;

- Familiarity - repeated contact with a person or thing facilitates sympathy. Therefore this permanent visual contact with the customer product, logo, increases the sales;

- Association - the positive connection. It works hand in hand with familiarity;

- Imitation shade - is a very strong influencing factor focused on nonverbal behaviors, that match those of the individual target. Mimicking the body positions in the mirror is a very powerful tool to influence.

\section{5. Authority}

Social environment takes its toll on how people think. Socially speaking, we have strong pressures for conformity and obedience in the face of authority, system of rules, family, school, etc. The message that we receive as small children, is that listening is a correctly interaction.

This social compliance tends to generate adaptive behaviors to views of "authority". Respect for them may appear irrational and manifests mainly by the inability to distinguish between the authority of law or any manipulator who presents himself as the authority of law. Representative for this principle is Milgram's experiment on 1961, on obedience to authority figures. It consisted of a series of social psychology experiments conducted by Yale University psychologist Stanley Milgram.

They measured the willingness of study participants to obey an authority figure who instructed them to perform acts conflicting with their personal conscience. The Milgram's study was published in the Journal of Abnormal and Social Psychology and later discussed his findings in greater depth in his 1974 book, Obedience to Authority: An Experimental View.

\section{6. Scarcity}

People tend to give more value to opportunities, resources or products when they are less available. If there are fewer resources and less time to get them, we tend to want them more. Things usually difficult to obtain are more valuable. If a product is rare or hard to get, people tend to buy more of that product. They act like that because of competitiveness (Cialdini, 2001). You see people overbidding, pay much more than the value of a product if the product has the character of rare, limited access (limited) and especially if the product has an emotional charge that makes it difficult critical thinking. 


\section{CONCLUSIONS}

Communication is divided into: convictive communication and persuasive communication. Convictive communication consists of the positive aspects of rational, argumentative, reasonable, honestly cooperative approaches (Vladutescu, 2006). Conviction is also another triumph over the universal powers of the logos, above the humors and subjective opinions of interlocutors (Convinco, ere, ici, victum -1 . To prove someone as guilty; 2 . To clearly show, prove something as wrong or true. Con, from convinco, means together with, and vinco - to conquer, to triumph, to outrun, to master, to be succeed in proving, to demonstrate, to make give in...) To convince $=$ to make someone adopt an opinion based on evidence and arguments, to make someone admit something as being true. To persuade $=$ to convince someone to believe, to think or to (want to) do a certain thing (leaves the truth aside) (DEX, 1996,154, p. 681 and p. 194). The results of persuasion are much greater and far more thorough, because that who gives in before it is aware they freely adhered to a thesis, driven not by the elementary evidence, but requested by an axiological transfer of the action of thinking (Vladutescu, 2014).

\section{ACKNOWLEDGMENT}

This work was partially supported by the grant number $33 \mathrm{C} / 2014$, awarded in the internal grant competition of the University of Craiova.

\section{References}

[1] Aristotle (1961). Organon, Vol. IV: Topica, Respingerile sofistice. Bucureşti: Editura Stiintifica.

[2] Andrzej Borowski, International Letters of Social and Humanistic Sciences 14 (2014) 7-17.

[3] Jason L. Powell, International Letters of Social and Humanistic Sciences 16(2) (2014) 177-183.

[4] Aristotel (2004). Retorica. București: Editura IRI.

[5] Aristotel (1998). Metafizica A-E. București: Editura Paideia.

[6] Ştefan Vlăduțescu (2008). Mesaje şi texte gânditoare. Craiova: Editura Sitech.

[7] Aristotel (1996). Metafizica. Bucuresti: Editura Iri.

[8] George A. Miller (1968). The Magical Number Seven, Plus or Minus Two.

[9] Ştefan Vlăduțescu (2004). Studii de Psihologie generală şi Psihologie socială. Craiova: Editura Sitech.

[10] R. B. Cialdini (2001). Influence: Science and practice (4th ed.). Boston: Allyn \& Bacon.

[11] Dale Carnegie (1964). How To Win Friends And Influence People. McGraw.

[12] Andy Szekely (2013). Comunica, Influenteaza, Convinge. Bucureşti: As Publishing. 
[13] Richard Gaylord Briley (1995). The Seven Spiritual Secrets of Success. Thomas Nelson Publishers.

[14] Andrzej Borowski, International Letters of Social and Humanistic Sciences 14 (2014) $33-41$.

[15] Florentin Smarandache, Ştefan Vlăduţescu (2014). Communication Neutrosophic Routes. Columbus, OH: Educational Publishing.

[16] Andrzej Borowski, International Letters of Social and Humanistic Sciences 4 (2013) $70-74$.

[17] Ioan Constantin Dima, Ştefan Vlăduţescu (2012). Persuasion elements used in logistical negotiation: Persuasive logistical negotiation. Saarbrucken: LAP Lambert Academic Publishing.

[18] Alina Tenescu, Mirela Teodorescu, Communications in Applied Sciences 2(1) (2014).

[19] Ştefan Vlăduţescu (2013). What Kind of Communication Is Philosophy. Jokull.

[20] Daniela Gîfu, Mirela Teodorescu, International Letters of Social and Humanistic Sciences 17 (2014) 119-127.

[21] Andrezj Borowski, International Letters of Social and Humanistic Sciences 2 (2014) 110-121.

[22] Florentin Smarandache, Ştefan Vlăduţescu (2014). Neutrosophic Emergences and Incidences. Saarbrucken: LAP Lambert Academic Publishing.

[23] Ioan Constantin Dima, Mirela Teodorescu, Daniela Gifu, International Letters of Social and Humanistic Sciences 20 (2014) 46-55

[24] Tomáš Hes, Anna Poledňáková, International Letters of Social and Humanistic Sciences 2 (2013) 18-31.

[25] Ştefan Vlăduţescu (2013). A battle with uncertainty 1 of the communication as an Academic discipline: title uncertainty. Studies on Literature, Discourse and Multicultural Dialogue, 493-504.

[26] Donovan A. McFarlane, International Letters of Social and Humanistic Sciences 4 (2013) 35-44.

[27] Andrezj Borowski, International Letters of Social and Humanistic Sciences 3 (2013) 69-74.

[28] Ş. Vlăduţescu, E. M. Ciupercă (2013). Next Flood Level of Communication: Social Networks. Aachen: Shaker Verlag.

[29] Daniela Gîfu, Mirela Teodorescu, International Letters of Social and Humanistic Sciences 18 (2014) 34-38.

[30] A. Borowski, International Letters of Social and Humanistic Sciences 11 (2014) 1-168.

[31] Ștefan Vlăduțescu (2013). Principle of the Irrepressible Emergence of the Message. Jokull.

[32] Andrzej Borowski, International Letters of Social and Humanistic Sciences 3 (2013) 46-53. 
[33] Ștefan Vlăduțescu, International Letters of Social and Humanistic Sciences 10 (2014) 100-106.

[34] Kinga Dziwańska, International Letters of Social and Humanistic Sciences 7 (2013) 96-112.

[35] Ștefan Vlăduțescu, International Letters of Social and Humanistic Sciences 7 (2014) 8-13.

[36] Colhon M. (2013). Automatic Lexical Alignment between Syntactically Weak Related Languages. Application for English and Romanian. In Computational Collective Intelligence. Technologies and Applications (pp. 266-275). Springer Berlin Heidelberg.

[37] Janusz Grabara, Michal Kolcun, Sebastian Kot, International Journal of Education and Research 2(2) (2014).

[38] Dumitru Zamfir, Ştefan Vlăduţescu (2003). Percepţia şi audiopercepția, o abordare cognitiv-constructiv-operaţioanală. Bucureşti: Editura Didactică şi Pedagogică.

[39] Sebastian Kot, Janusz Grabara, Michal Kolcun, International Letters of Social and Humanistic Sciences 15 (2014) 1-6.

[40] Ştefan Vlăduțescu, Journal of Sustainable Development Studies 6(1) (2014).

[41] Marian Siminică, Aurelia Traistaru, International Journal of Education and Research 1(12) (2013).

[42] Stefan Vladutescu, Analele Universităţii din Craiova. Seria Ştiinţe Filologice. Lingvistică (1-2) (2013) 355-363.

[43] Max G. Craig, Journal of Studies in Social Sciences 8(1) (2014).

[44] Jason L. Powell, International Letters of Social and Humanistic Sciences 7 (2014) 22-30.

[45] Aurelia Traistaru, Marioara Avram, International Letters of Social and Humanistic Sciences 13 (2014) 79-88.

[46] Ştefan Vlăduțescu, Communications in Applied Sciences 2(2) (2014).

[47] Agnieszka Ulfik, Stefan Nowak, Polish Journal of Environmental Studies 23(3) (2014).

[48] J. Tabor, Place of Non-formal Education in the Career Building Process. Polish Journal of Management Studies.

[49] B. Slusarczyk, A. Broniszewska, Entrepreneurship of Women in Poland and the EuQuantitative Analysis. Polish Journal of Management Studies.

[50] Vlad Roşca, Theoretical and Applied Economics 1(1) (2012) 127.

[51] Sebastian Kot, Beata Ślusarczyk, The Journal of American Business Review Cambridge (2014).

[52] Ștefan Vlăduțescu, International Letters of Social and Humanistic Sciences 15(2) (2014) 164-170.

[53] R. Y. Papancheva, K. A. Dimitrova, K. N. Manev (2010). Teaching IT in the Primary School-Some Aspects of Propaedeutics of Informatics Knowledge. In CSEDU (2) (pp. 185-188). 
[54] Tomáš Hes, Alena Neradová, Karel Srnec, International Letters of Social and Humanistic Sciences 7 (2013) 55-75.

[55] Ştefan Vlăduţescu, International Letters of Social and Humanistic Sciences 25 (2014) $16-24$.

[56] Ştefan Vlăduţescu, European Scientific Journal 9(32) (2013).

[57] G. Rajović, J. Bulatović, International Letters of Natural Sciences 1 (2014) 33-53.

[58] Ștefan Vlăduțescu (2006). Comunicare jurnalistică negativăa. Bucureşti: Editura Academiei.

[59] Aurika Komsaare, International Journal of Learning 16(6) (2009).

[60] J. H. Gasderell, International Letters of Social and Humanistic Science 22 (2014) 85-91.

[61] Vladimir Modrak, Mirela Teodorescu, Daniela Gîfu, International Letters of Social and Humanistic Sciences 24 (2014) 56-65.

[62] Jason L. Powell, International Letters of Social and Humanistic Sciences 16(2) (2014) 132-143.

[63] Napoleon Hill (1928). The Law of Success. Ralston University Press.

[64] Jason L. Powell, International Letters of Social and Humanistic Sciences 17(1) (2014) $1-60$. 